\title{
Are there Multiple Cells of Origin of Merkel Cell Carcinoma?
}

\author{
J. C. Sunshine ${ }^{1}$, N. S. Jahchan ${ }^{2}$, J. Sage ${ }^{2}$, and J. Choi ${ }^{1,3}$ \\ ${ }^{1}$ Department of Dermatology, Northwestern University, Feinberg School of Medicine, Chicago, IL \\ 60611, USA \\ ${ }^{2}$ Departments of Genetics and Pediatrics, Stanford University School of Medicine, Stanford, CA \\ 94305, USA \\ ${ }^{3}$ Department of Biochemistry, Molecular Genetics, and the Center for Genetic Medicine, \\ Northwestern University, Feinberg School of Medicine, Chicago, IL 60611, USA
}

\section{Abstract}

Merkel cell carcinoma (MCC) is a rare but lethal cancer with the highest case-by-case fatality rate among all skin cancers. $80 \%$ of cancers are associated with the Merkel cell polyomavirus (MCPyV). $20 \%$ of MCCs are virus negative. Recent epidemiological data suggest that there are important, clinically relevant differences between these two subtypes of MCC. Recent studies in cancer genomics, mouse genetics, and virology experiments have transformed our understanding of MCC pathophysiology. Importantly, dramatic differences in the genetics of these two MCC subtypes suggest fundamental differences in their pathophysiology. We review these recent works and find that they provocatively suggest that MCPyV-positive and MCPyV-negative MCCs arise from two different cells of origin: the MCPyV-negative MCC from epidermal keratinocytes and the MCPyV-positive MCC from dermal fibroblasts. If true, this would represent the first cancer that we are aware of that evolves from cells of origin from two distinct germ layers: MCPyVnegative MCCs from ectodermal keratinocytes and MCPyV-positive MCCs from mesodermal fibroblasts. Future epigenetic experiments may prove valuable in confirming these distinct lineages for these MCC subtypes, especially for the clinical importance the cell of origin has on MCC treatment and prevention.

\section{Introduction}

Merkel Cell Carcinoma (MCC) is a highly aggressive primary skin cancer with a case-bycase fatality rate worse than stage-matched melanomas. It usually presents as a rapidly growing pink-red dome-shaped nodule with a strong preference for sun-exposed areas. ${ }^{1}$ Histologically, MCC are small blue cell tumors tightly packed into sheets or trabecular arrays that express neuroendocrine markers with scant cytoplasm. ${ }^{2}$ The name for MCCs comes from the structural and immunohistochemical (IHC) characteristics they share with Merkel cells. However, there has been substantial debate in the literature about the cells of

Users may view, print, copy, and download text and data-mine the content in such documents, for the purposes of academic research, subject always to the full Conditions of use: http://www.nature.com/authors/editorial_policies/license.html\#terms

Conflict of Interest

The authors state no conflict of interest. 
origin of MCC, with various groups suggesting that MCCs do not arise from Merkel cells but instead arise from epidermal stem cells, ${ }^{3}$ dermal stem cells, ${ }^{4}$ or pre-/pro-B cells. ${ }^{5,6}$

Recently, there have been dramatic advances in our understanding of the molecular underpinnings of MCC. In 2008, Chang, Moore, and colleagues discovered that $\sim 80 \%$ of MCCs are associated with the Merkel Cell Polyomavirus (MCPyV). ${ }^{7}$ The virus appears to be cancer promoting. In MCPyV-positive MCCs but not in other cell types, the MCPyV virus is clonally integrated into the host genome. These MCPyV-positive MCCs durably express viral oncoproteins that are normally transiently expressed in the viral life cycle. ${ }^{7}$

The MCPyV genome has diverged from other human polyomaviruses but still encodes for the oncoproteins Large T (LT) and Small T (ST) antigens. ${ }^{8}$ While the LT antigen of polyomaviruses binds to and represses both RB and p53, MCPyV LT specifically inhibits RB function but cannot bind $553 .{ }^{9}$ In contrast to ST antigens from other polyomaviruses, the MCPyV ST antigen does not require binding to the protein phosphatase 2a protein to promote carcinogenesis. Instead, its oncogenic activity derives from a protein domain that binds to and inhibits multiple E3 ligation proteins including FBW7. ${ }^{10}$ Underscoring the oncogenic properties of MCPyV ST and LT antigens, downregulation of LT or ST expression impairs the viability and growth of MCPyV-positive MCC. ${ }^{11-13}$ Importantly, however, in $20 \%$ of MCCs, there is no evidence of clonal viral integration or expression of viral oncoproteins, suggesting that these tumors are MCPyV-negative. ${ }^{7}$

Recent epidemiological data suggest that there are clinically relevant differences between these two populations. The highest worldwide incidence of MCCs is found in Australia, a country with a predominantly Caucasian population with high year round UV exposure. ${ }^{14}$ Notably, as compared to the USA and elsewhere where $~ 80 \%$ of MCC are MCPyV-positive, the MCC burden in Australia is substantially skewed towards virus negative tumors. ${ }^{15} \mathrm{In}$ addition, MCPyV-negative tumors are less frequently found on extremities and more frequently found in the head and neck as compared to MCPyV-positive tumors. ${ }^{16}$ Importantly, this difference appears to be clinically significant, as MCPyV-negative tumors appear to be more aggressive with increased risk of progression (HR 1.77) and death (HR = 1.85) due to MCC. ${ }^{16}$ This highlights the need to understand the distinct pathophysiology of MCPyV-negative and MCPyV-positive MCCs. ${ }^{17,} 18$

Cancer is fundamentally a genetic disease. To advance our understanding of the genetic bases of MCC, we and others recently performed exome sequencing of MCCs MCPyVpositive and MCPyV-negative MCCs. ${ }^{19-21}$ These efforts provided novel insights into the distinct pathogeneses of virus-positive and virus-negative MCCs and led us to revisit important fundamental questions about MCC biology including its cell(s) of origin.

The number and nature of somatic mutations in cancer are a function of cell-intrinsic and environmental factors. Multiple groups have shown that mutational analysis can enable lineage tracing to follow cells as they evolve during health and disease. For example, mutational signatures can be used to infer the environmental exposures to potential carcinogens. ${ }^{22}$ This has been used in cancer to track the life histories of tumors, inferring the stem cell origin of cancer, ${ }^{23}$ and tracking tumor evolution during tumor metastasis ${ }^{24}$ and 
acquired drug resistance. ${ }^{25}$ We utilize these data, in combination with other recent discoveries, to posit that virus-positive and virus-negative MCCs have different cells of origin from two different germ layers.

\section{Distinct life histories of virus-positive and virus-negative MCC}

Exome sequencing of MCCs has provided important insights into the pathophysiology and targetability of the disease. ${ }^{19-21}$ Notably, these sequencing efforts confirm the low prevalence of potentially targetable mutations, particularly in the PI-3-kinase pathway in MCCs. In addition, they provide the genetic explanation for the immunogenicity of MCPyVnegative MCCs, namely the high incidence of tumor neoantigens. ${ }^{19-21}$

Strikingly, we and others observed that the mutational burden in MCCs is bimodal. ${ }^{19-21}$ One cohort has a relatively low mutation burden, $0.4-0.75$ mutations/Mb, which is lower than that of any epithelial cancers sequenced by the Cancer Genome Atlas (TCGA). This cohort (the MCPyV-associated MCCs) 1) harbors clonal levels of MCPyV DNA, 2) expresses MCPyV T antigens, 3) generates antibodies to $\mathrm{T}$ antigens in their hosts, and 4) is found in areas characteristic of MCPyV-positive MCCs. ${ }^{19-21}$

In contrast, the other cohort (the MCPyV-negative MCCs) is associated with an exceptionally high mutation burden $(\sim 40$ mutations/Mb) that is higher than any cancer sequenced by the TCGA and $\sim 100$-fold higher than virus-positive MCCs (Figure 1a). ${ }^{19-21}$ These cancers do not show evidence of viral integration or expression of viral proteins. Additionally, they are preferentially found in anatomical locations characteristic of MCPyVnegative MCCs like the head and neck. ${ }^{26}$

In theory, differences in mutation burden may be due to differences in genetic drivers. For example, virally-driven cancers may harbor fewer mutations than non-virally-driven cancers, because the expression of viral oncogenes obviates the need for additional cancer-promoting mutations. While this may be true, a comparison to head and neck squamous cell carcinomas (HNSCCs) suggest that other factors may be at play (Figure 1a). Like MCCs, HNSCCs are either virus-independent or associated with a virus that encodes viral oncogenes (human papillomavirus). In contrast to MCCs, virus-associated and virus-negative HNSCCs have little to no differences in the mutational burden. ${ }^{27,28}$

The types of mutations are also profoundly different between MCPyV-negative and MCPyVpositive MCCs. The mutational signature of MCPyV-positive MCC does not show evidence of any exposure to known mutagens. Instead, the MCPyV-positive mutational signature is typical of mutations that accumulate during aging. In contrast, MCPyV-negative MCCs harbor a strong ultraviolet signature. ${ }^{19,21,29}$ These data strongly suggest that the cell of origin of the MCPyV-negative MCC but not of the MCPyV-positive MCC has been extensively exposed to ultraviolet light. As mentioned above, this genetic difference is supported by the epidemiological data showing relative dominance of the MCPyV-negative tumors in Australia. ${ }^{15}$

One potential explanation is that MCPyV-positive MCCs occur strictly in sun-shielded areas. However, we know from epidemiological data that, with a few exceptions, this is not the 
case. ${ }^{26}$ We therefore posit an alternative explanation: the cell of origin for MCC originates in two distinct niches in the skin, with one protected from UV light (for MCPyV-positive MCC), and the other residing in a compartment with heavy exposure to UV irradiation (for MCPyV-negative MCC).

\section{Merkel cells may not be the cell of origin for MCCs}

Even though MCCs share certain features with Merkel cells, emerging data suggest that Merkel cells are not the cells of origin. Merkel cells are oval shaped osmoreceptors and mechanoreceptors essential for light touch sensation. ${ }^{30}$ They reside in the stratum basale. This causes our first conflict - while Merkel cells are fundamentally epidermal, the vast majority of MCCs are dermal or subcuticular. ${ }^{31}$ Second, while MCCs share some markers with Merkel cells, there are important differences. For example, although cytokeratin 20 (CK20) is expressed in both Merkel cells and MCCs, its pattern of expression differs sharply. In Merkel cells, CK20 is loosely arranged, leading to diffuse CK20 immunohistochemical staining in the cytoplasm. In contrast, in MCCs, CK20 are organized in characteristic whorl- or plaque-like arrangements, leading to the classic dot-like staining pattern on IHC. ${ }^{32}$ Third, MCCs express a number of markers such as c-kit, CD171, and CD24 that are not expressed in Merkel cells. ${ }^{33}$ Fourth, Merkel cells appear to be terminally differentiated with limited proliferative potential and slow turnover. Dying Merkel cells appear to be replaced not by proliferating Merkel cells but rather by differentiated pluripotent epidermal stem cells. ${ }^{34}$ These data may explain the absence of data supporting proliferation of Merkel cells in vivo. For instance, many other cells from the skin proliferate leading to the appearance of benign tumors, e.g. fibroblasts, fibromas; sebocytes, sebaceous adenomas; adipocytes, lipomas; melanocytes, nevi; keratinocytes, seborrheic keratosis. ${ }^{2}$ In contrast, there are no known benign Merkel cell tumors.

\section{Failure to generate Mouse Models of MCC using Merkel cell-specific Cre drivers}

Efforts to generate mouse models of MCC utilizing Merkel cell-specific Cre drivers have largely failed. MCPyV-negative MCCs have frequent mutations in TP53 (73\%-100\%) and $R B 1$ (45\%-100\%), and less commonly but notably in the PI-3-kinase pathway (up to $18 \%$ of cases). ${ }^{19,21}$ To develop an in vivo model of MCPyV-negative MCCs, the Sage lab generated mutant mice in a C57BL/6;129Sv/J mixed genetic background with deletions of relevant tumor suppressors ( $T p 53$; three components of the RB family ( $R b 1, p 107$, and $p 130)$; and a component of the PI-3-kinase pathway (Pten)). Triple knockout (TKO) mice harbored floxed alleles in $T p 53, R b 1$, and $p 130$ (as described in ${ }^{35}$ ). Quadruple knockout (QKO) mice also harbored floxed alleles in Pten $^{36}$ or a null allele for $p 107.37$ These mice were crossed with mice harboring Cre-ERT2 expressed from the Atoh11 promoter. Atoh1 encodes a lineagespecific protein (ATOH1, also known as MATH1) that is expressed in Merkel cells and is required for Merkel cell differentiation. ${ }^{38}$ In these mice, low frequencies of Merkel cells were found to re-enter the cell cycle 5 days after Tamoxifen administration (no more than $20 \%$ - N.J. and J.S., data not shown). Through the end of study (12 to 15 months after Tamoxifen administration), no advanced and aggressive tumors were formed (Table 1). A 
few benign lesions were observed on the ears or the back of mice (N.J. and J.S., data not shown). To rule out the role of additional UV-induced mutations, Atoh1-CreER ${ }^{T 2} ;$ TKO and Atoh1-CreER ${ }^{T 2}$; $Q K O$ mice were exposed to daily UV-B at $300 \mathrm{~J} / \mathrm{m}^{2}$ for two weeks. None of these mice developed MCCs. Strikingly, parallel experiments with similar mutant alleles in similar genetic backgrounds show efficient tumor initiation and development of aggressive neuroendocrine lung cancer. ${ }^{39}$ These negative results suggest that adult Merkel cells are not a likely cell of origin for MCPyV-negative MCC.

To make a mouse model of MCPyV-positive MCCs, Shuda et al. conditionally expressed the small $\mathrm{T}$ antigen from Merkel cells (Table 1). This model is reasonable because the vast majority of MCPyV-positive MCCs do not have cancer-promoting somatic mutations. ${ }^{19} \mathrm{In}$ addition, although both LT and ST antigens appear to contribute to proliferation and survival in vitro, multiple in vitro and in vivo experiments suggest that expression of MCPyV-derived ST antigen alone is sufficient for transformation. ${ }^{13}$ The model they employed used a loxstop-lox strategy with the MCPyV small T antigen expressed in the Rosa26locus wherein the gene would be induced by a tissue specific Cre. They also targeted Merkel cell-specific expression by using a Cre expressed from the Atoh1 promoter $^{40}$ Strikingly, this model also failed to generate tumors. In fact, selective expression of ST antigen had no effect on Merkel cell numbers in the adult mice. These negative results suggest that adult Merkel cells are also not a likely cell of origin for MCPyV-positive MCC.

There are multiple reasons why these models might have failed to induce MCCs. For example, there may be important issues regarding the strain, host immune status, and need for additional sensitizing mutations. Nevertheless, in combination with the clinical data presented above, these results suggest that Merkel cells may not be a cell of origin for MCC. In contrast, emerging evidence from transgenic mice indicates that expression of LT or ST in keratinocytes (K14- or K5-positive cells) can result in oncogenic effects, even though these mice do not develop MCC (Table 1). ${ }^{10,41,42}$ This suggests that other cells in the skin such as keratinocytes may serve as cells of origin for MCC.

\section{An epidermal origin of MCPyV-negative MCC}

The genomic data suggest that the epidermal keratinocyte may be the cell of origin for MCPyV-negative MCCs. First, MCPyV-negative MCCs harbor a UV mutational signature, which is characteristic of epidermal-derived cancers. 86\% of mutations in MCPyV-negative MCCs are $\mathrm{C}>\mathrm{T}$ transitions, the majority of which (66\% of total) have the trinucleotide context characteristic of UV-mediated DNA damage. ${ }^{19,21,29}$ The same UV signature is found only in proliferations of epidermal cells, including keratinocyte clones in "normal" eyelid skin, actinic keratosis, and squamous cell carcinoma (SCC), ${ }^{43,}{ }^{44}$ melanocytic nevi and melanomas, ${ }^{45,46}$ and even cutaneous $\mathrm{T}$ cell lymphomas ${ }^{47}$ (Figure 1a).

Secondly, mutation burden in epidermal cancers is a function of the specific epidermal cell of origin. Cutaneous $\mathrm{T}$ cell lymphomas harbor $\sim 3.2$ mutations/Mb, melanomas $\sim 14$ mutations/Mb, and keratinocyte derived basal cell or squamous cell carcinomas 50-75 mutations/Mb. ${ }^{43-47}$ With a median of $\sim 40$ mutations/Mb and over $1000 \mathrm{SNVs}$ per exome, the mutational burden of MCPyV-negative MCCs is significantly higher than any cancer 
sequenced by the TCGA including melanomas and is in line only with two other cancer types, both keratinocyte-derived skin cancers (Figure 1a). ${ }^{19-21}$ In addition to the overall mutational burden being compatible with a keratinocyte origin, MCPyV-negative MCC harbor mutations in NOTCH1, HRAS, and FAT1 that are also frequently mutated in SCCs. ${ }^{48}$

Other orthogonal data support this hypothesis. Many other skin cancers can be observed in collision tumors between the cancers themselves and precursor lesions derived from the same cell of origin. This is true for both melanomas, which may arise within melanocytic nevi, and SCCs, which can be found contiguous with actinic keratoses. ${ }^{46,49}$ There are no reported cases of collision tumors of MCCs and benign proliferations of Merkel cells, but there are 18 case reports of collision tumors between MCCs and keratinocytic neoplasms, such as SCC and SCC in situ. ${ }^{50-52}$ In all of these cases, the MCCs are MCPyV-negative, had an extremely high mutational burden, and had a direct physical connection to epidermal keratinocytes. Given that $\sim 80 \%$ of MCCs are viral-associated, the absence of MCPyVpositive MCCs in these collision tumors is unlikely to occur by chance alone ( $\mathrm{p}<0.0001$; chisquare test). These findings instead suggest that these collision tumors occur because MCCs, like SCCs, are derived from keratinocytes. Alternatively, both SCCs and MCCs can arise from the same epidermal stem cell population, which can differentiate into both keratinocytes and Merkel cells (Figure 1b). ${ }^{53}$

\section{A dermal origin for MCPyV-positive MCC}

In contrast, the genetic data suggest that the MCPyV-positive MCCs may be derived from a completely distinct, dermal cell of origin. Unlike any epidermal-derived cancers, MCPyVpositive MCCs harbor very few mutations. The few mutations that are found do not harbor a UV signature (Figure 1a). These data would appear to exclude epidermal cells, e.g. epidermal keratinocytes, melanocytes, and Merkel cells, as the cell of origin of MCPyVpositive MCCs. Such data highlight the potential for dramatic differences in the pathophysiology of MCPyV and MCPyV-positive MCCs.

Recent virology experiments suggest that dermal fibroblasts may be the target of $\mathrm{MCPyV}$ infection and thus a putative cell of origin for MCPyV-positive MCCs. Liu and colleagues infected the skin with both a MCPyV-Green Fluorescent Protein (GFP) pseudovirus and the full MCPyV virus. They found that while MCPyV can deliver reporter DNA to a wide variety of cells in the skin, MCPyV could not infect CK20-positive Merkel cells. Moreover, only dermal cells expressing fibroblast markers were capable of expressing the MCPyV LT and ST antigens. Lastly, they showed that ex vivo, dermal fibroblasts were the only cell types that can support the full viral life cycle: viral entry, viral transcription, and viral replication. ${ }^{54}$ Consistent with their potential role in MCC initiation, dermal fibroblasts have a mutation burden $(0.15-0.37$ mutations $/ \mathrm{Mb})$ and mutational signature similar to MCPyVpositive MCCs. 55,56

\section{Neuroendocrine transdifferentiation via inhibition of RB}

If the two main MCC subtypes are derived from different cells of origin, how could they look similar pathologically? Multiple lines of evidence support the possibility of cancer cell 
plasticity, wherein divergent cell types can acquire neuroendocrine phenotypes. The molecular mechanism underlying this lineage plasticity remains unclear; however, many of these phenotypic changes appear to result as a consequence of dysregulation of RB and/or p53. 57,58

Like MCPyV LT antigen, the LT antigen of a related polyomavirus (SV40) inhibits RB. Ectopic expression of SV40 LT antigen is sufficient to induce neuroendocrine transdifferentiation in mouse models of gastric and prostate cancer even when initially expressed from non-neuroendocrine cells. In a model of gastric cancer, SV40 LT antigens were expressed from gastric epithelial cells using a gastric parietal cell-specific Cre driver (Atp4b-Cre). Instead of developing gastric adenocarcinoma, as originally anticipated, these mice instead developed exclusively neuroendocrine carcinomas. ${ }^{59}$ Similarly, in a mouse model of prostate cancer, SV40 T antigens are expressed in prostate epithelial cells using probasin promoters as a driver. These mice initially develop adenocarcinoma followed by an epithelial to neuroendocrine transition during tumor progression and metastasis. ${ }^{60}$

In humans, $R B 1$ and $T P 53$ mutations confer drug resistance in human prostate cancer and in $E G F R$ mutant lung cancer. Remarkably, these mutations appear to induce epigenetic reprogramming of the cancer cells leading to lineage plasticity. This is characterized by induction of chromatin modifying enzymes, e.g. EZH2, and transcription factors, e.g. SOX2, leading to dramatic phenotypic changes, including appearance of neuroendocrine features. 61,62 In lung cancer, EGFR mutant lung adenocarcinomas that are resistant to tyrosine kinase inhibitors can acquire a neuroendocrine small cell lung cancer phenotype. ${ }^{63}$ Because $R B 1$ and TP53 are frequently mutated in MCPyV-negative MCCs, these mutations may promote transdifferentiation into a Merkel cell-like, neuroendocrine phenotype.

\section{Conclusions}

Despite considerable recent advances in MCC biology and treatment, the cell of origin of MCCs remains in question. Parsing out the true cells of origin may be important for the development of relevant pre-clinical models and an eventual cure. Recent genomics studies suggest that MCPyV-negative and -positive MCCs are distinct entities, arising from distinct cells-of origin residing in different parts of the skin. Conceptually this leads us to propose that MCCs results from convergent tumor evolution, whereby two different cells of origin transdifferentiate into a shared neuroendocrine phenotype through inhibition of RB either through somatic mutations or expression of LT and ST antigens (Figure 1b).

This model may be testable utilizing a combination of epigenetic techniques and mouse models. Unbiased approaches such as ATAC-seq and RNA-seq may show that MCCs retain epigenetic features that are shared with their cell of origin, i.e. keratinocytes and dermal fibroblasts. Similarly, alternative keratinocyte-derived (or epidermal stem cell-derived) or dermal fibroblast Cre-drivers, respectively, may be able to functionally demonstrate the ability of these cells in vivo to initiate models of virus-negative and virus-positive MCCs, respectively. Development of such models could provide for a robust platform for preclinical development of MCC targeted therapeutics. 


\section{Acknowledgments}

J.C. is the Ruth K. Freinkel Assistant Professor of Dermatology. J.C. is supported by the NCI (K08 CA 191019). J.S. is the Harriet and Mary Zelencik Scientist in Children's Cancer and Blood Diseases. The mouse work was supported by the NCI (R21 CA167104-01). Mice were maintained according to practices prescribed by the NIH at Stanford's Research Animal Facility accredited by the AAPLAC (protocol 13565). We thank Dr. David MacPherson for the Pten mutant mice and Dr. Anton Berns for the Trp53 mutant mice. We would like to thank everyone in the Sage laboratory who helped in the generation and characterization of all the mutant mouse cohorts, specifically Margaret Zhu, Kim Tran, Garrett Seitz, and Anuradha Tathireddy, as well as Dr. Jinah Kim for help with the histopathology.

\section{Bibliography}

1. Harms KL, Healy MA, Nghiem P, Sober AJ, Johnson TM, Bichakjian CK, et al. Analysis of Prognostic Factors from 9387 Merkel Cell Carcinoma Cases Forms the Basis for the New 8th Edition AJCC Staging System. Ann Surg Oncol. 2016; 23:3564-3571. [PubMed: 27198511]

2. Elston, D., Ferringer, T., Ko, CJ., Peckham, S., High, WA., DiCaudo, DJ. Dermatopathology. Elsevier Health Sciences; 2013.

3. Lemasson G, Coquart N, Lebonvallet N, Boulais N, Galibert MD, Marcorelles P, et al. Presence of putative stem cells in Merkel cell carcinomas. J Eur Acad Dermatol Venereol. 2012; 26:789-795. [PubMed: 21615527]

4. Visscher D, Cooper PH, Zarbo RJ, Crissman JD. Cutaneous neuroendocrine (Merkel cell) carcinoma: an immunophenotypic, clinicopathologic, and flow cytometric study. Mod Pathol. 1989; 2:331-338. [PubMed: 2668940]

5. Zur Hausen A, Rennspiess D, Winnepenninckx V, Speel EJ, Kurz AK. Early B-cell differentiation in Merkel cell carcinomas: clues to cellular ancestry. Cancer Res. 2013; 73:4982-4987. [PubMed: 23576560]

6. Sauer CM, Haugg AM, Chteinberg E, Rennspiess D, Winnepenninckx V, Speel EJ, et al. Reviewing the current evidence supporting early B-cells as the cellular origin of Merkel cell carcinoma. Crit Rev Oncol Hematol. 2017; 116:99-105. [PubMed: 28693804]

7. Feng H, Shuda M, Chang Y, Moore PS. Clonal integration of a polyomavirus in human Merkel cell carcinoma. Science. 2008; 319:1096-1100. [PubMed: 18202256]

8. Wendzicki JA, Moore PS, Chang Y. Large T and small T antigens of Merkel cell polyomavirus. Curr Opin Virol. 2015; 11:38-43. [PubMed: 25681708]

9. Houben R, Dreher C, Angermeyer S, Borst A, Utikal J, Haferkamp S, et al. Mechanisms of p53 restriction in Merkel cell carcinoma cells are independent of the Merkel cell polyoma virus $\mathrm{T}$ antigens. J Invest Dermatol. 2013; 133:2453-2460. [PubMed: 23563200]

10. Verhaegen ME, Mangelberger D, Harms PW, Vozheiko TD, Weick JW, Wilbert DM, et al. Merkel cell polyomavirus small T antigen is oncogenic in transgenic mice. J Invest Dermatol. 2015; 135:1415-1424. [PubMed: 25313532]

11. Houben R, Adam C, Baeurle A, Hesbacher S, Grimm J, Angermeyer S, et al. An intact retinoblastoma protein-binding site in Merkel cell polyomavirus large $\mathrm{T}$ antigen is required for promoting growth of Merkel cell carcinoma cells. Int J Cancer. 2012; 130:847-856. [PubMed: 21413015]

12. Houben R, Shuda M, Weinkam R, Schrama D, Feng H, Chang Y, et al. Merkel cell polyomavirusinfected Merkel cell carcinoma cells require expression of viral T antigens. J Virol. 2010; 84:7064-7072. [PubMed: 20444890]

13. Shuda M, Chang Y, Moore PS. Merkel cell polyomavirus-positive Merkel cell carcinoma requires viral small T-antigen for cell proliferation. J Invest Dermatol. 2014; 134:1479-1481. [PubMed: 24217011]

14. Schadendorf D, Lebbe C, Zur Hausen A, Avril MF, Hariharan S, Bharmal M, et al. Merkel cell carcinoma: Epidemiology, prognosis, therapy and unmet medical needs. Eur J Cancer. 2017; 71:53-69. [PubMed: 27984768] 
15. Garneski KM, Warcola AH, Feng Q, Kiviat NB, Leonard JH, Nghiem P. Merkel cell polyomavirus is more frequently present in North American than Australian Merkel cell carcinoma tumors. J Invest Dermatol. 2009; 129:246-248. [PubMed: 18650846]

16. Moshiri AS, Doumani R, Yelistratova L, Blom A, Lachance K, Shinohara MM, et al. Polyomavirus-Negative Merkel Cell Carcinoma: A More Aggressive Subtype Based on Analysis of 282 Cases Using Multimodal Tumor Virus Detection. J Invest Dermatol. 2017; 137:819-827. [PubMed: 27815175]

17. Kaufman HL, Russell J, Hamid O, Bhatia S, Terheyden P, D’Angelo SP, et al. Avelumab in patients with chemotherapy-refractory metastatic Merkel cell carcinoma: a multicentre, single-group, openlabel, phase 2 trial. Lancet Oncol. 2016; 17:1374-1385. [PubMed: 27592805]

18. Nghiem PT, Bhatia S, Lipson EJ, Kudchadkar RR, Miller NJ, Annamalai L, et al. PD-1 Blockade with Pembrolizumab in Advanced Merkel-Cell Carcinoma. N Engl J Med. 2016; 374:2542-2552. [PubMed: 27093365]

19. Goh G, Walradt T, Markarov V, Blom A, Riaz N, Doumani R, et al. Mutational landscape of MCPyV-positive and MCPyV-negative Merkel cell carcinomas with implications for immunotherapy. Oncotarget. 2016; 7:3403-3415. [PubMed: 26655088]

20. Harms PW, Vats P, Verhaegen ME, Robinson DR, Wu YM, Dhanasekaran SM, et al. The Distinctive Mutational Spectra of Polyomavirus-Negative Merkel Cell Carcinoma. Cancer Res. 2015; 75:3720-3727. [PubMed: 26238782]

21. Wong SQ, Waldeck K, Vergara IA, Schröder J, Madore J, Wilmott JS, et al. UV-Associated Mutations Underlie the Etiology of MCV-Negative Merkel Cell Carcinomas. Cancer Res. 2015; 75:5228-5234. [PubMed: 26627015]

22. Alexandrov LB, Nik-Zainal S, Wedge DC, Aparicio SA, Behjati S, Biankin AV, et al. Signatures of mutational processes in human cancer. Nature. 2013; 500:415-421. [PubMed: 23945592]

23. Puram RV, Kowalczyk MS, de Boer CG, Schneider RK, Miller PG, McConkey M, et al. Core Circadian Clock Genes Regulate Leukemia Stem Cells in AML. Cell. 2016; 165:303-316. [PubMed: 27058663]

24. Jones S, Chen WD, Parmigiani G, Diehl F, Beerenwinkel N, Antal T, et al. Comparative lesion sequencing provides insights into tumor evolution. Proc Natl Acad Sci U S A. 2008; 105:42834288. [PubMed: 18337506]

25. Choi J, Landrette SF, Wang T, Evans P, Bacchiocchi A, Bjornson R, et al. Identification of PLX4032-resistance mechanisms and implications for novel RAF inhibitors. Pigment Cell Melanoma Res. 2014; 27:253-262. [PubMed: 24283590]

26. Heath M, Jaimes N, Lemos B, Mostaghimi A, Wang LC, Penas PF, et al. Clinical characteristics of Merkel cell carcinoma at diagnosis in 195 patients: the AEIOU features. J Am Acad Dermatol. 2008; 58:375-381. [PubMed: 18280333]

27. Stransky N, Egloff AM, Tward AD, Kostic AD, Cibulskis K, Sivachenko A, et al. The mutational landscape of head and neck squamous cell carcinoma. Science. 2011; 333:1157-1160. [PubMed: 21798893]

28. Network CGA. Comprehensive genomic characterization of head and neck squamous cell carcinomas. Nature. 2015; 517:576-582. [PubMed: 25631445]

29. Gonzalez-Vela MD, Curiel-Olmo S, Derdak S, Beltran S, Santibanez M, Martinez N, et al. Shared Oncogenic Pathways Implicated in Both Virus-Positive and UV-Induced Merkel Cell Carcinomas. J Invest Dermatol. 2017; 137:197-206. [PubMed: 27592799]

30. Maricich SM, Wellnitz SA, Nelson AM, Lesniak DR, Gerling GJ, Lumpkin EA, et al. Merkel cells are essential for light-touch responses. Science. 2009; 324:1580-1582. [PubMed: 19541997]

31. Sibley RK, Dehner LP, Rosai J. Primary neuroendocrine (Merkel cell?) carcinoma of the skin. I. A clinicopathologic and ultrastructural study of 43 cases. Am J Surg Pathol. 1985; 9:95-108. [PubMed: 2579594]

32. Moll I, Roessler M, Brandner JM, Eispert AC, Houdek P, Moll R. Human Merkel cells--aspects of cell biology, distribution and functions. Eur J Cell Biol. 2005; 84:259-271. [PubMed: 15819406]

33. Tilling T, Moll I. Which are the cells of origin in merkel cell carcinoma? J Skin Cancer. 2012; 2012:680410. [PubMed: 23304516] 
34. Van Keymeulen A, Mascre G, Youseff KK, Harel I, Michaux C, De Geest N, et al. Epidermal progenitors give rise to Merkel cells during embryonic development and adult homeostasis. J Cell Biol. 2009; 187:91-100. [PubMed: 19786578]

35. Schaffer BE, Park KS, Yiu G, Conklin JF, Lin C, Burkhart DL, et al. Loss of p130 accelerates tumor development in a mouse model for human small-cell lung carcinoma. Cancer Res. 2010; 70:3877-3883. [PubMed: 20406986]

36. Cui M, Augert A, Rongione M, Conkrite K, Parazzoli S, Nikitin AY, et al. PTEN is a Potent Suppressor of Small Cell Lung Cancer. Mol Cancer Res. 2014

37. Viatour P, Somervaille TC, Venkatasubrahmanyam S, Kogan S, McLaughlin ME, Weissman IL, et al. Hematopoietic stem cell quiescence is maintained by compound contributions of the retinoblastoma gene family. Cell Stem Cell. 2008; 3:416-428. [PubMed: 18940733]

38. Lumpkin EA, Collisson T, Parab P, Omer-Abdalla A, Haeberle H, Chen P, et al. Math1-driven GFP expression in the developing nervous system of transgenic mice. Gene Expr Patterns. 2003; 3:389395. [PubMed: 12915300]

39. Semenova EA, Nagel R, Berns A. Origins, genetic landscape, and emerging therapies of small cell lung cancer. Genes Dev. 2015; 29:1447-1462. [PubMed: 26220992]

40. Shuda M, Guastafierro A, Geng X, Shuda Y, Ostrowski SM, Lukianov S, et al. Merkel Cell Polyomavirus Small T Antigen Induces Cancer and Embryonic Merkel Cell Proliferation in a Transgenic Mouse Model. PLoS One. 2015; 10:e0142329. [PubMed: 26544690]

41. Verhaegen ME, Mangelberger D, Harms PW, Eberl M, Wilbert DM, Meireles J, et al. Merkel cell polyomavirus small $\mathrm{T}$ antigen initiates Merkel cell carcinoma-like tumor development in mice. Cancer Res. 2017

42. Spurgeon ME, Cheng J, Bronson RT, Lambert PF, DeCaprio JA. Tumorigenic activity of merkel cell polyomavirus $\mathrm{T}$ antigens expressed in the stratified epithelium of mice. Cancer Res. 2015; 75:1068-1079. [PubMed: 25596282]

43. Chitsazzadeh V, Coarfa C, Drummond JA, Nguyen T, Joseph A, Chilukuri S, et al. Cross-species identification of genomic drivers of squamous cell carcinoma development across preneoplastic intermediates. Nat Commun. 2016; 7:12601. [PubMed: 27574101]

44. Martincorena I, Roshan A, Gerstung M, Ellis P, Van Loo P, McLaren S, et al. Tumor evolution. High burden and pervasive positive selection of somatic mutations in normal human skin. Science. 2015; 348:880-886. [PubMed: 25999502]

45. Hodis E, Watson IR, Kryukov GV, Arold ST, Imielinski M, Theurillat JP, et al. A landscape of driver mutations in melanoma. Cell. 2012; 150:251-263. [PubMed: 22817889]

46. Shain AH, Yeh I, Kovalyshyn I, Sriharan A, Talevich E, Gagnon A, et al. The Genetic Evolution of Melanoma from Precursor Lesions. N Engl J Med. 2015; 373:1926-1936. [PubMed: 26559571]

47. Choi J, Goh G, Walradt T, Hong BS, Bunick CG, Chen K, et al. Genomic landscape of cutaneous T cell lymphoma. Nat Genet. 2015; 47:1011-1019. [PubMed: 26192916]

48. South AP, Purdie KJ, Watt SA, Haldenby S, den Breems N, Dimon M, et al. NOTCH1 mutations occur early during cutaneous squamous cell carcinogenesis. J Invest Dermatol. 2014; 134:2630 2638. [PubMed: 24662767]

49. Ratushny V, Gober MD, Hick R, Ridky TW, Seykora JT. From keratinocyte to cancer: the pathogenesis and modeling of cutaneous squamous cell carcinoma. J Clin Invest. 2012; 122:464472. [PubMed: 22293185]

50. Busam KJ, Jungbluth AA, Rekthman N, Coit D, Pulitzer M, Bini J, et al. Merkel cell polyomavirus expression in merkel cell carcinomas and its absence in combined tumors and pulmonary neuroendocrine carcinomas. Am J Surg Pathol. 2009; 33:1378-1385. [PubMed: 19609205]

51. Pulitzer MP, Brannon AR, Berger MF, Louis P, Scott SN, Jungbluth AA, et al. Cutaneous squamous and neuroendocrine carcinoma: genetically and immunohistochemically different from Merkel cell carcinoma. Mod Pathol. 2015; 28:1023-1032. [PubMed: 26022453]

52. Vieites B, Suarez-Penaranda JM, Delgado V, Vazquez-Veiga H, Varela J, Forteza J. Merkel cell carcinoma associated with in situ and invasive squamous cell carcinoma. Acta Derm Venereol. 2009; 89:184-186. [PubMed: 19326009]

53. Woo SH, Stumpfova M, Jensen UB, Lumpkin EA, Owens DM. Identification of epidermal progenitors for the Merkel cell lineage. Development. 2010; 137:3965-3971. [PubMed: 21041368] 
54. Liu W, Yang R, Payne AS, Schowalter RM, Spurgeon ME, Lambert PF, et al. Identifying the Target Cells and Mechanisms of Merkel Cell Polyomavirus Infection. Cell Host Microbe. 2016; 19:775787. [PubMed: 27212661]

55. Milholland B, Dong X, Zhang L, Hao X, Suh Y, Vijg J. Differences between germline and somatic mutation rates in humans and mice. Nat Commun. 2017; 8:15183. [PubMed: 28485371]

56. Gore A, Li Z, Fung HL, Young JE, Agarwal S, Antosiewicz-Bourget J, et al. Somatic coding mutations in human induced pluripotent stem cells. Nature. 2011; 471:63-67. [PubMed: 21368825]

57. Tschaharganeh DF, Xue W, Calvisi DF, Evert M, Michurina TV, Dow LE, et al. p53-dependent Nestin regulation links tumor suppression to cellular plasticity in liver cancer. Cell. 2014; 158:579-592. [PubMed: 25083869]

58. Wikenheiser-Brokamp KA. Rb family proteins differentially regulate distinct cell lineages during epithelial development. Development. 2004; 131:4299-4310. [PubMed: 15294860]

59. Syder AJ, Karam SM, Mills JC, Ippolito JE, Ansari HR, Farook V, et al. A transgenic mouse model of metastatic carcinoma involving transdifferentiation of a gastric epithelial lineage progenitor to a neuroendocrine phenotype. Proc Natl Acad Sci U S A. 2004; 101:4471-4476. [PubMed: 15070742]

60. Kaplan-Lefko PJ, Chen TM, Ittmann MM, Barrios RJ, Ayala GE, Huss WJ, et al. Pathobiology of autochthonous prostate cancer in a pre-clinical transgenic mouse model. Prostate. 2003; 55:219237. [PubMed: 12692788]

61. Ku SY, Rosario S, Wang Y, Mu P, Seshadri M, Goodrich ZW, et al. Rb1 and Trp53 cooperate to suppress prostate cancer lineage plasticity, metastasis, and antiandrogen resistance. Science. 2017; 355:78-83. [PubMed: 28059767]

62. Mu P, Zhang Z, Benelli M, Karthaus WR, Hoover E, Chen CC, et al. SOX2 promotes lineage plasticity and antiandrogen resistance in TP53- and RB1-deficient prostate cancer. Science. 2017; 355:84-88. [PubMed: 28059768]

63. Niederst MJ, Sequist LV, Poirier JT, Mermel CH, Lockerman EL, Garcia AR, et al. RB loss in resistant EGFR mutant lung adenocarcinomas that transform to small-cell lung cancer. Nat Commun. 2015; 6:6377. [PubMed: 25758528]

64. Jayaraman SS, Rayhan DJ, Hazany S, Kolodney MS. Mutational landscape of basal cell carcinomas by whole-exome sequencing. J Invest Dermatol. 2014; 134:213-220. [PubMed: 23774526]

65. Pickering CR, Zhou JH, Lee JJ, Drummond JA, Peng SA, Saade RE, et al. Mutational landscape of aggressive cutaneous squamous cell carcinoma. Clin Cancer Res. 2014; 20:6582-6592. [PubMed: 25303977]

66. McGirt LY, Jia P, Baerenwald DA, Duszynski RJ, Dahlman KB, Zic JA, et al. Whole-genome sequencing reveals oncogenic mutations in mycosis fungoides. Blood. 2015; 126:508-519. [PubMed: 26082451]

67. Turajlic S, Furney SJ, Lambros MB, Mitsopoulos C, Kozarewa I, Geyer FC, et al. Whole genome sequencing of matched primary and metastatic acral melanomas. Genome Res. 2012; 22:196-207. [PubMed: 22183965]

68. Furney SJ, Turajlic S, Stamp G, Thomas JM, Hayes A, Strauss D, et al. The mutational burden of acral melanoma revealed by whole-genome sequencing and comparative analysis. Pigment Cell Melanoma Res. 2014; 27:835-838. [PubMed: 24913711] 


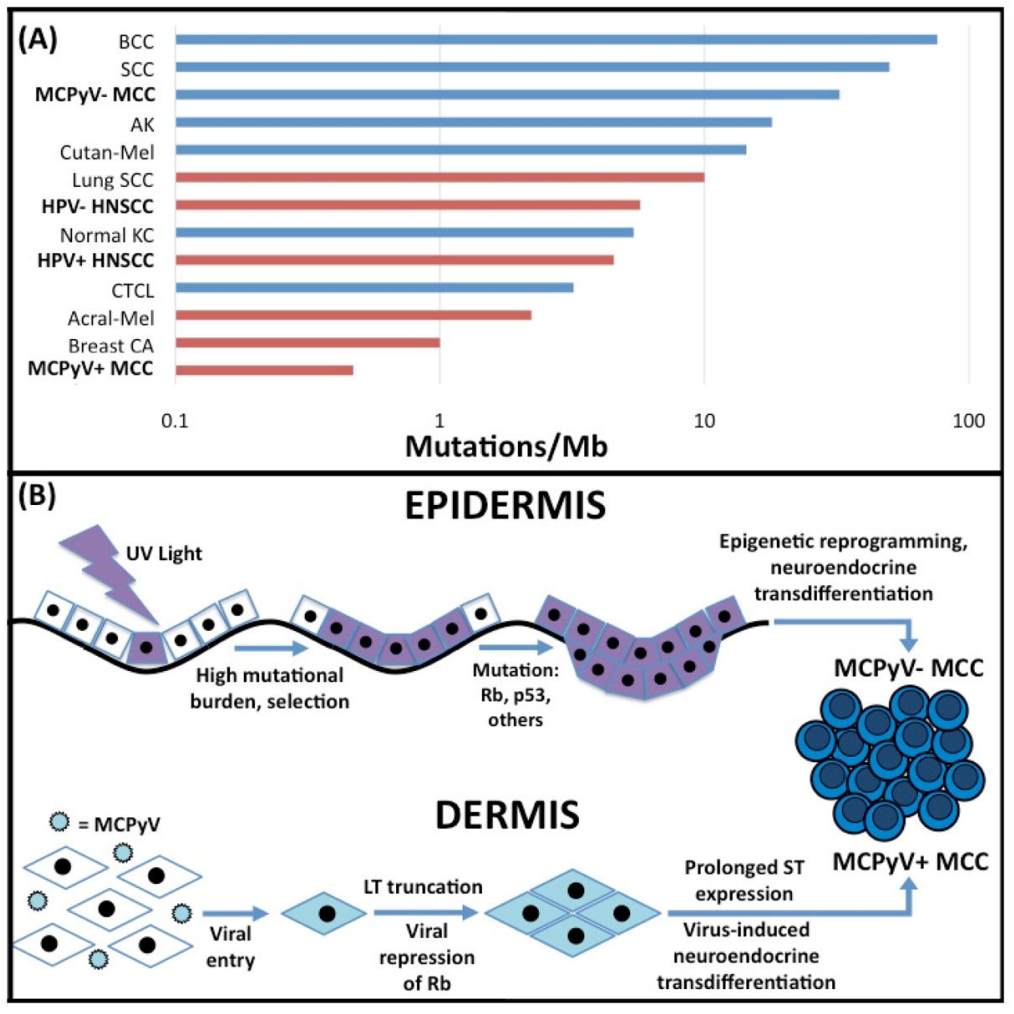

Figure 1.

(A) Mutational Burden of Skin and Selected Non-Skin Cancers for Comparison Blue bars = dominant UV signature. Red bars = non-dominant/lack UV signature. $\mathrm{BCC}=$ Basal Cell Carcinoma ${ }^{64}$; SCC $=$ Cutaneous Squamous Cell Carcinoma ${ }^{43}, 65$; MCPyV- or + MCC $=$ Merkel Cell Polyoma Virus negative or positive Merkel Cell Carcinoma ${ }^{19,20,29}$; AK $=$ Actinic Keratosis ${ }^{43}$; Cutan-Mel $=$ Cutaneous Melanoma ${ }^{45}$; Lung SCC $=$ Lung Adenocarcinoma $^{22}$; HNSCC $=$ Head and Neck Squamous Cell Carcinoma ${ }^{27,28}$; KC = Keratinocyte $^{43,44}$; CTCL $=$ Cutaneous T cell Lymphoma ${ }^{47,66}$; Acral Melanoma ${ }^{67,68}$; Breast $\mathrm{CA}=$ Breast Adenocarcinoma ${ }^{22}$

(B) Schema Depicting Model of Convergent Development of MCPyV- and MCPyV+ MCC. In the epidermis, a keratinocyte precursor is depicted undergoing UV mutagenesis, positive selection, mutation in $\mathrm{Rb}$ and $\mathrm{p} 53$, and neuroendocrine transdifferentiation resulting in MCPyV- MCC. In the dermis, MCPyV enters dermal fibroblasts, undergoes LT truncation leading to viral repression of $\mathrm{Rb}$, sustained $\mathrm{ST}$ expression, and eventual virus-induced neuroendocrine transdifferentiation resulting in $\mathrm{MCPyV}+\mathrm{MCC}$. 


\section{Table 1}

\section{Mouse models of MCC}

\begin{tabular}{|c|c|c|}
\hline Model & Phenotype & Reference \\
\hline $\begin{array}{l}\text { Developmental induction of MCPyV early region } \\
\text { (with small T and large T antigens) in K14-positive } \\
\text { cells (K14-cre Lox-stop-Lox MCPyV early) }\end{array}$ & $\begin{array}{c}\text { Mice develop hyperplasia, hyperkeratosis, and acanthosis of } \\
\text { the skin, some mice develop cutaneous papillomas - some } \\
\text { proliferation in Merkel cells }\end{array}$ & $\begin{array}{l}\text { Spurgeon et al. } \\
\text { Cancer Res, } 2015^{42}\end{array}$ \\
\hline $\begin{array}{l}\text { Postnatal induction of MCPyV small T antigen in } \\
\text { K5-positive cells (K5-creER Lox-stop-Lox ST Ag) }\end{array}$ & $\begin{array}{l}\text { Epidermal transformation and squamous cell carcinoma in } \\
\text { situ - No expression of MCC markers in skin lesions }\end{array}$ & $\begin{array}{l}\text { Verhaegen et al. J } \\
\text { Invest Dermatol, } \\
\quad 2015^{10}\end{array}$ \\
\hline $\begin{array}{l}\text { Postnatal induction of small T antigen and loss of } \\
\text { p53 in Atoh1-positive cells (Atoh1-creER Lox-stop- } \\
\text { Lox ST Ag and p53 flox/flox) }\end{array}$ & $\begin{array}{c}\text { Some effects of ST expression in Atoh1-positive cells during } \\
\text { embryonic development but no effects on Merkel cells } \\
\text { numbers and no MCC in adults }\end{array}$ & $\begin{array}{l}\text { Shuda et al. J Invest } \\
\text { Dermatol, } 2015^{40}\end{array}$ \\
\hline $\begin{array}{l}\text { Developmental induction of MCPyV small T and } \\
\text { large T antigens and Atoh1 under the control of the } \\
\text { K5 promoter in transgenic mice }\end{array}$ & $\begin{array}{l}\text { MCC-like intraepidermal lesions in pre-term embryos with } \\
\text { expression of Atoh1 and ST - No additional effect of LT }\end{array}$ & $\begin{array}{l}\text { Verhaegen et al. } \\
\text { Cancer Res, } 2017^{41}\end{array}$ \\
\hline $\begin{array}{l}\text { Postnatal deletion of tumor suppressor genes in } \\
\text { Atoh1-positive cells (Atoh1-creER, and } \\
\text { combinations of p53 flox/flox, Rb flox/flox, p130 } \\
\text { flox/flox, pten flox/flox, and p107 null) }\end{array}$ & $\begin{array}{c}\text { Combined deletion of } \mathrm{Rb} / \mathrm{p} 53 / \mathrm{p} 130, \mathrm{Rb} / \mathrm{p} 53 / \mathrm{p} 130 / \mathrm{p} 107, \text { or } \\
\mathrm{Rb} / \mathrm{p} 53 / \mathrm{Pten} \text { after induction of Cre by tamoxifen in nursing } \\
\text { mothers or young adult mice }+ \text { groups of mice exposed to } \\
\text { ultraviolet light }- \text { proliferation in } 20 \% \text { of Merkel cells, small } \\
\text { lesions observed mostly on ears in around } 10-30 \% \text { of mice, } \\
\text { no MCC (over } 20 \text { mice tested per cohort, aged at least } 12 \\
\text { months) }\end{array}$ & $\begin{array}{l}\text { Jahchan and Sage } \\
\text { unpublished }\end{array}$ \\
\hline
\end{tabular}

